\title{
Effect of production system and slaughter age on some production traits of guinea fowl: Meat quality and digestive traits
}

\author{
M. Sarica ${ }^{1}$, M.A. Boz ${ }^{2}$, U.S. Yamak ${ }^{1 \#}$ \& A. Ucar ${ }^{3}$ \\ ${ }^{1}$ Department of Animal Science, Agricultural Faculty, Ondokuz Mayis University, Samsun, 55139, Turkey \\ ${ }^{2}$ Department of Animal Science, Agricultural Faculty, Bozok University, Yozgat, 66900, Turkey \\ ${ }^{3}$ Department of Animal Science, Agricultural Faculty, Ankara University, Ankara, 06110, Turkey
}

(Received 20 July 2018; Accepted 10 December 2018; First published online 27 March 2019)

\author{
Copyright resides with the authors in terms of the Creative Commons Attribution 4.0 South African Licence. \\ See: http://creativecommons.org/licenses/by/4.0/za \\ Condition of use: The user may copy, distribute, transmit and adapt the work, but must recognise the authors and
} the South African Journal of Animal Science.

\begin{abstract}
Certain meat quality traits of guinea fowl that were reared in two production systems were determined in this study. Grey guinea fowl were reared in free-range and barn conditions. Birds were slaughtered at 14 , 16 and 18 weeks old to determine meat quality traits. Some digestive traits were also determined. The type of production system affected the yellowness of breast meat significantly, and guinea fowl reared in the freerange system had yellower breast meat. The $\mathrm{pH}$ of both breast and thigh meat increased at older ages. Water-holding capacity, cooking loss and drip loss of breast and thigh meat were not affected by production system. Drip loss of meat decreased at older slaughter ages. The ratios of digestive system organ weights to body weight mostly decreased at older ages.
\end{abstract}

Keywords: Digestive tract, free-range, meat colour, water holding capacity, $\mathrm{pH}$

\# Corresponding author: usyamak@omu.edu.tr

\section{Introduction}

Demand for guinea fowl meat is increasing throughout the world. In terms of production, guinea fowl is the cheapest poultry meat to produce in some countries, particularly those in Africa (Saina, 2005). In terms of consumption, game birds are popular among consumers in many countries. When compared with broilers, guinea fowl meat is reported to have higher protein and lower fat contents (CAB, 1987). Moreover, as a good source of vitamins, niacin and iron, and with a flavour comparable with game meat, it has been argued that guinea fowl merits a better price than chicken (Ajala et al., 2007).

Most consumers of alternative poultry species, such as guinea fowl, have certain expectations of flavour. However, most studies that focused on guinea-fowl meat quality were conducted in barn conditions (Bernacki et al., 2012; Tufarelli \& Laudadio, 2015). Birds reared under such conditions have a different flavour and more fat than game birds, probably because of their limited exercise (USDA, 2015). It is important to assess the market in areas where demand for guinea fowl products has high potential (Madzimure et al., 2011), especially if consumers are given the choice of products from various systems. By raising guinea fowl under semi-intensive 'free-range' farming conditions, it may be possible to achieve a taste that is similar to game-bird meat and thus increase the market potential of guinea-fowl meat. Given the few studies that have compared the meat quality of guinea fowl reared indoors and those raised in freerange systems, this study therefore examined the effects of production system (indoor barn and free-range) on certain production traits of guinea fowl.

\section{Material and Methods}

This trial was conducted at the Research Farm of the Agricultural Faculty of Ondokuz Mayis University, Turkey in May-August 2015. All procedures were approved by Ondokuz Mayis University Ethical Committee for Experimental Animals. Eggs were collected from a flock of grey guinea fowl (Numida meleagris) from Yozgat Breeding Station of the Turkish Ministry of Forests and Water Affairs. All eggs were 
collected and transferred to the farm's hatchery on the same day. After a 25-day incubation period, 200 dayold chicks were randomly selected for use in the experiment.

Chicks were randomly allocated to pens that belonged to either an indoor or outdoor-access (free range) production system, and were interspersed in windowed houses, with four pens per system and 25 chicks per pen. Pens $(3.5 \times 3.5 \mathrm{~m})$ were separated and covered with $0.5 \times 0.5 \mathrm{~cm}$ wire mesh to prevent birds from flying between pens. Each pen contained one round feeder and one round drinker. The indoor pens also contained an 8-cm layer of wood shavings as litter, with no fresh litter being added during the production period. Heating was provided by infra-red heaters, and economical white bulbs were used for lighting. A 24-hour light regimen was applied for the first three days. Light was incrementally decreased to 20 hours over days 3 - 14 and then remained constant until six weeks, after which natural lighting (approximately 14 hours/day) was applied until slaughter. After they were six weeks old, birds in the outdoor free-range system were given 24-hour access to outdoor pens measuring $14 \times 3.5 \mathrm{~m}$ through a single doorway measuring $50 \mathrm{x}$ $90 \mathrm{~cm}$.

All birds were fed ad libidum with the same commercial layer chicken diet based on corn and soybean meal (190 g crude protein (CP) and $11.72 \mathrm{MJ}$ metabolizable energy (ME), $10.0 \mathrm{~g}$ lysine, $4.0 \mathrm{~g}$ methionine, $11.0 \mathrm{~g} \mathrm{Ca}, 7.0 \mathrm{~g} \mathrm{P}, 120 \mathrm{mg} \mathrm{Mn}, 15 \mathrm{mg} \mathrm{Cu}, 100 \mathrm{mg} \mathrm{Zn} \mathrm{per} \mathrm{kg)} \mathrm{until} 12$ weeks old and then with layer chicken developer diet (160 g CP, $11.30 \mathrm{MJ}$ ME, $3.50 \mathrm{~g}$ methionine, $7.20 \mathrm{~g}$ lysine, $10.0 \mathrm{~g} \mathrm{Ca}, 4.00 \mathrm{~g} \mathrm{P})$ until the end of the experiment. Water was also provided ad libidum.

All birds were wing-banded and weighed individually at hatch, 2, 4, 6, 8, 10, 12, 14, 16 and 18 weeks old. Feed consumption, feed conversion ratios and mortality were evaluated by replication.

At 14, 16 and 18 weeks old, four birds (two males, two females) per pen were slaughtered after an 8-hour fasting period. Live weights were recorded prior to slaughter. Scalding (1 min at $\left.56{ }^{\circ} \mathrm{C}\right)$, picking, coldwater chilling, vent opening, evisceration and air-chilling were performed with semi-automated equipment. The gastrointestinal tract, from the oesophagus to the cloaca, and organs were carefully excised. Weight and length of the whole tract were recorded after remaining digesta were emptied. Empty weights of the proventriculus, spleen, pancreas and craw were recorded. All these weights were expressed as a percentage of live weight just before slaughter.

Meat $\mathrm{pH}$ was measured at three points on the left leg (two on the thigh and one on the drumstick) and three points on the left breast using a pH meter (Model PC 510, Cyber scan, Singapore) after chilling for 12 hours at $4{ }^{\circ} \mathrm{C}$. Meat colour $\left(L^{*} a^{*} b^{*}\right)$ was evaluated at two points on the left thigh and two points on the left breast (Fanatico et al., 2007; Sarica et al., 2011) using a colorimeter (Konica Minolta CR-400 colorimeter). Mean values for colour and $\mathrm{pH}$ values were calculated and recorded.

Drip loss was evaluated by suspending one intact fillet in a sealed glass box for 48 hours at $2-4{ }^{\circ} \mathrm{C}$ and expressed as percentage of weight loss during storage (Bianchi et al., 2007). Whole samples of both breast and leg muscles $(20 \mathrm{~g})$ were placed in uncovered aluminum pans and roasted in an electric oven, which had been pre-heated to $200{ }^{\circ} \mathrm{C}$ for 15 min, until meat samples reached an internal temperature of 80 ${ }^{\circ} \mathrm{C}$. Samples were cooled for $30 \mathrm{~min}$ to about $15^{\circ} \mathrm{C}$ and dried on the surface with paper towels. Cooking loss was estimated as the percentage of the weight of the roasted samples to the raw ones (Castellini et al., 2002). Meat water-holding capacity (WHC) was determined by calculating the weight loss of a 1-g sample after centrifuging it for $4 \mathrm{~min}$ at $1500 \times \mathrm{g}$ and drying it overnight at $70^{\circ} \mathrm{C}$ (Castellini et al., 2002).

Statistical analysis was performed using the software SPSS, version 16. Analysis of variance with a factorial arrangement was used to test the effects of production system, age, sex and the interactions among these factors. Data percentages were subjected to arc-sine transformation, and slaughter-age means were separated using Duncan's multiple range test. A level of $P<0.05$ was considered statistically significant.

\section{Results}

Colour and $\mathrm{pH}$ values of guinea fowl meat are given in Table 1. Breast-meat yellowness $\left(\mathrm{b}^{\star}\right)$ was affected by production system $(P<0.05)$ and $\operatorname{sex}(P<0.01)$, and thigh-meat redness $\left(\mathrm{a}^{\star}\right)$ was affected by slaughter age $(P<0.01)$.

No other colour values were affected significantly by production system, slaughter age or sex. Production system, slaughter age and sex had significant affects on meat $\mathrm{pH}$, with thigh $\mathrm{pH}$ of indoor guinea fowl higher than that of free-range guinea fowl $(P<0.01)$, breast $\mathrm{pH}$ higher in males than females $(P<0.05)$, and both breast and thigh $\mathrm{pH}$ increasing with slaughter age $(P<0.01)$. (Interactions between production system, slaughter age and sex were found insignificant for all traits and are thus not shown in Table 1.)

Water holding capacity, cooking loss, and drip loss values of guinea-fowl meat are given in Table 2 . WHC was not affected significantly by production system, slaughter age or sex $(P>0.05)$. Cooking loss was not affected significantly by production system, slaughter age or sex, with the exception of thigh-meat cooking loss, which was significantly lower at 18 weeks in comparison with other slaughter ages $(P<0.05)$. Drip loss of breast and thigh meat was also significantly lower at 18 weeks old compared with other 
slaughter ages (Table 2) $(P<0.01)$ but was not affected by production system or sex. (Interactions between production system, slaughter age, and sex were found insignificant for all traits and are thus not shown in Table 2.)

Table 1 Colour and $\mathrm{pH}$ values of guinea fowl meat at different ages

\begin{tabular}{|c|c|c|c|c|c|c|c|c|c|c|}
\hline \multirow{2}{*}{$\begin{array}{l}\text { Production } \\
\text { System }\end{array}$} & \multirow{2}{*}{$\begin{array}{c}\text { Slaughter } \\
\text { Age } \\
\text { (weeks) }\end{array}$} & \multirow{2}{*}{ Sex } & \multicolumn{3}{|c|}{ Breast colour } & \multicolumn{3}{|c|}{ Thigh colour } & \multirow{2}{*}{$\begin{array}{c}\text { Breast } \\
\text { pH }\end{array}$} & \multirow{2}{*}{$\begin{array}{c}\text { Thigh } \\
\text { pH }\end{array}$} \\
\hline & & & $\mathbf{L}$ & $\mathbf{a}$ & b & $\mathbf{L}$ & $\mathbf{a}$ & b & & \\
\hline \multirow{6}{*}{ Free-range } & \multirow{2}{*}{14} & $M$ & 57.91 & 4.26 & 5.63 & 54.06 & 6.50 & 2.02 & 6,59 & 6,71 \\
\hline & & $\mathrm{F}$ & 57.15 & 4.06 & 7.13 & 55.58 & 6.58 & 1.50 & 6,56 & 6,74 \\
\hline & \multirow{2}{*}{16} & M & 58.06 & 4.08 & 7.25 & 54.66 & 8.72 & 2.18 & 6,73 & 6,99 \\
\hline & & $\mathrm{F}$ & 58.05 & 3.66 & 8.72 & 55.47 & 7.53 & 1.88 & 6,66 & 6,89 \\
\hline & \multirow{2}{*}{18} & $M$ & 59.84 & 3.74 & 7.38 & 54.20 & 9.03 & 2.59 & 6,71 & 7,13 \\
\hline & & $\mathrm{F}$ & 58.75 & 3.20 & 9.23 & 54.06 & 8.12 & 3.11 & 6,71 & 7,23 \\
\hline \multirow{6}{*}{ Indoor } & \multirow{2}{*}{14} & $M$ & 57.75 & 3.56 & 5.25 & 55.89 & 6.61 & 1.34 & 6,64 & 6,87 \\
\hline & & $\mathrm{F}$ & 60.23 & 3.58 & 8.47 & 55.67 & 7.85 & 4.21 & 6,58 & 6,85 \\
\hline & \multirow{2}{*}{16} & M & 59.26 & 3.28 & 5.00 & 55.57 & 7.13 & 0.83 & 6,67 & 6,94 \\
\hline & & $\mathrm{F}$ & 57.96 & 3.58 & 7.68 & 57.22 & 7.75 & 2.88 & 6,64 & 6,94 \\
\hline & \multirow{2}{*}{18} & M & 58.50 & 3.17 & 5.13 & 53.21 & 7.74 & 1.99 & 6,79 & 7,25 \\
\hline & & $\mathrm{F}$ & 59.32 & 3.51 & 8.06 & 54.90 & 7.75 & 1.99 & 6,74 & 7,30 \\
\hline SEM & & & 0.539 & 0.134 & 0.250 & 0.448 & 0.142 & 0.261 & 0.009 & 0.014 \\
\hline \multicolumn{11}{|l|}{ Effects } \\
\hline \multirow{2}{*}{\multicolumn{2}{|c|}{ Production system }} & FR & 58.30 & 3.83 & 7.55 & 54.67 & 7.67 & 2.21 & 6.66 & 6.94 \\
\hline & & IN & 58.84 & 3.45 & 6.59 & 55.41 & 7.47 & 2.21 & 6.67 & 7.03 \\
\hline \multirow{3}{*}{\multicolumn{2}{|c|}{ Slaughter age }} & 14 & 58.26 & 3.86 & 6.61 & 55.30 & $6.88 \mathrm{a}$ & 2.67 & $6.59 a$ & $6.79 a$ \\
\hline & & 16 & 58.33 & 3.65 & 7.16 & 55.73 & $7.67 \mathrm{~b}$ & 1.93 & $6.67 \mathrm{~b}$ & $6.94 b$ \\
\hline & & 18 & 59.10 & 3.40 & 7.45 & 54.10 & $8.16 b$ & 2.42 & $6.74 \mathrm{c}$ & $7.23 c$ \\
\hline \multirow{2}{*}{\multicolumn{2}{|c|}{ Sex }} & M & 58.55 & 3.68 & 5.93 & 54.60 & 7.54 & 1.82 & 6.68 & 6.98 \\
\hline & & $\mathrm{F}$ & 58.57 & 3.60 & 8.21 & 55.48 & 7.60 & 2.59 & 6.65 & 6.99 \\
\hline \multicolumn{3}{|l|}{ Production system } & NS & NS & * & NS & NS & NS & NS & $\star *$ \\
\hline \multicolumn{3}{|l|}{ Slaughter age } & NS & NS & NS & NS & $* *$ & NS & $* *$ & $\star *$ \\
\hline \multicolumn{3}{|l|}{ Sex } & NS & NS & $\star \star$ & NS & NS & NS & * & NS \\
\hline
\end{tabular}

a, b, c: Means within columns with no common superscript letter differ significantly (*: $P<0.05$; $*$ : $P<0.01$ )

SEM: standard error of means, NS: insignificant; FR: free-range, IN: indoor; M: male, F: female

Digestive-tract traits are given in Table 3. Production system did not affect any of digestive tract traits significantly. The ratio of total digestive tract weight to live weight was significantly affected by slaughter age and was highest at 14 weeks old $(P<0.05)$. The ratios of spleen weight and proventriculus weight to live weight were also significantly affected by slaughter age. Sex affected only proventriculus weight/live weight ratio, and this was found to be higher in females. Slaughter age had a significant effect on small intestine length, which decreased with slaughter age $(P<0.01)$. Interactions between production system, slaughter age and sex were found insignificant for all traits and thus are not shown in Table 3.

\section{Discussion}

Consumer demand is one of the most important factors that drive producers to raise animals in freerange systems. By rearing birds in an alternative production system such as a free-range system, the environmental conditions of the animals are improved, which decreases their stress levels, particularly for 
Table 2 Water holding capacity (\%), cooking loss (\%) and drip loss (\%) of breast and thigh meat of guinea fowl at different ages

\begin{tabular}{|c|c|c|c|c|c|c|c|c|}
\hline $\begin{array}{l}\text { Production } \\
\text { System }\end{array}$ & $\begin{array}{c}\text { Slaughter } \\
\text { age } \\
\text { (weeks) }\end{array}$ & Sex & $\begin{array}{c}\text { Breast } \\
\text { meat } \\
\text { WHC }\end{array}$ & $\begin{array}{l}\text { Thigh } \\
\text { meat } \\
\text { WHC }\end{array}$ & $\begin{array}{c}\text { Breast } \\
\text { meat } \\
\text { cooking } \\
\text { loss }\end{array}$ & $\begin{array}{c}\text { Thigh } \\
\text { meat } \\
\text { cooking } \\
\text { loss }\end{array}$ & $\begin{array}{l}\text { Breast } \\
\text { meat drip } \\
\text { loss }\end{array}$ & $\begin{array}{l}\text { Thigh } \\
\text { meat drip } \\
\text { loss }\end{array}$ \\
\hline \multirow{6}{*}{ Free-range } & \multirow{2}{*}{14} & M & 74.44 & 76.88 & 15.35 & 18.47 & 5.03 & 3.83 \\
\hline & & $\mathrm{F}$ & 74.89 & 75.83 & 13.66 & 15.89 & 5.28 & 4.00 \\
\hline & \multirow{2}{*}{16} & $M$ & 74.62 & 76.44 & 11.93 & 16.23 & 5.11 & 3.34 \\
\hline & & $\mathrm{F}$ & 72.20 & 77.22 & 14.93 & 19.42 & 4.35 & 4.39 \\
\hline & \multirow{2}{*}{18} & $M$ & 74.31 & 76.38 & 13.58 & 15.91 & 3.55 & 1.39 \\
\hline & & $\mathrm{F}$ & 74.62 & 76.61 & 13.52 & 15.01 & 3.71 & 1.1 \\
\hline \multirow{6}{*}{ Indoor } & \multirow{2}{*}{14} & $M$ & 74.97 & 75.76 & 13.60 & 16.62 & 4.31 & 5.21 \\
\hline & & $\mathrm{F}$ & 74.60 & 77.50 & 12.99 & 17.40 & 5.21 & 4.32 \\
\hline & \multirow{2}{*}{16} & M & 74.00 & 77.80 & 12.42 & 17.62 & 4.41 & 4.63 \\
\hline & & $\mathrm{F}$ & 74.08 & 76.61 & 12.71 & 17.17 & 5.84 & 4.32 \\
\hline & \multirow{2}{*}{18} & $M$ & 74.59 & 76.28 & 14.50 & 14.63 & 2.83 & 1.52 \\
\hline & & $\mathrm{F}$ & 75.12 & 76.16 & 13.57 & 14.87 & 3.12 & 1.54 \\
\hline SEM & & & 0,205 & 0,133 & 0.353 & 0.417 & 0.146 & 0.138 \\
\hline \multicolumn{9}{|l|}{ Effects } \\
\hline \multirow{2}{*}{\multicolumn{2}{|c|}{ Production system }} & FR & 74.18 & 76.56 & 13.83 & 16.82 & 4.51 & 3.14 \\
\hline & & IN & 74.56 & 76.35 & 13.30 & 16.39 & 4.29 & 3.59 \\
\hline \multirow{3}{*}{\multicolumn{2}{|c|}{ Slaughter age }} & 14 & 74.72 & 76.49 & 13.90 & $17.09 a$ & $4.96 a$ & $4.34 a$ \\
\hline & & 16 & 73.72 & 76.51 & 13.00 & $17.61 a$ & $4.93 a$ & $4.17 a$ \\
\hline & & 18 & 74.66 & 76.36 & 13.79 & $15.11 b$ & $3.30 \mathrm{~b}$ & $1.59 \mathrm{~b}$ \\
\hline \multirow{2}{*}{\multicolumn{2}{|c|}{ Sex }} & $M$ & 74.49 & 76.26 & 13.57 & 16.58 & 4.21 & 3.32 \\
\hline & & $\mathrm{F}$ & 74.25 & 76.65 & 13.56 & 16.63 & 4.59 & 3.34 \\
\hline \multicolumn{3}{|l|}{ Production system } & NS & NS & NS & NS & NS & NS \\
\hline \multicolumn{3}{|l|}{ Slaughter age } & NS & NS & NS & * & $* *$ & $* \star$ \\
\hline \multicolumn{3}{|l|}{ Sex } & NS & NS & NS & NS & NS & NS \\
\hline
\end{tabular}

animals such as game birds, which are not fully domesticated (Yamak et al., 2016). Consumer preferences are also strongly guided by meat colour, which can be affected by numerous factors (Fanatico et al., 2007), including production system, age and sex (Castellini et al., 2002; Yamak et al., 2016; Boz et al., 2017). In the present study, yellowness $\left(b^{\star}\right)$ values of guinea-fowl breast meat were significantly affected by production system $(P<0.05)$ and sex $(P<0.01)$, with $\mathrm{b}^{*}$ values significantly higher for females than for males $(8.21$ vs 5.93 ) and for birds reared in a free-range system as opposed to those raised indoors (7.55 vs 6.59). The higher $b^{*}$ value obtained in breast meat of females could be because of the higher fat content. It has been reported that females had higher fat content than males in poultry species (Nikolova et al., 2007). Birds also deposit a portion of adsorbed dietary pigments into the fat (Fletcher, 1992). It is also thought that higher $b^{*}$ values obtained in free-range guinea fowl is related to physical exercise during pasture. Other colour values were not affected by production system, slaughter age or sex. Overall $b^{*}$ values in this study ranged between 1.34 and 2.88 for thigh meat and between 5.13 and 8.72 for breast meat, which is higher than values for both thigh meat $(1.9-2.8)$ and breast meat $(4.7-6.5)$ that were reported in previous studies (Kokoszynski et al., 2011; Laudadio et al., 2012; Tufarelli \& Laudadio, 2015). Contrary to these findings, Lightness (L*) values in the present study, which ranged between 57.15 and 59.84 for breast meat and between 53.21 and 55.89 for thigh meat, were also higher than the values (46 - 50 for fowl breast meat and $41.78-42.6$ for thigh meat) 
Table 3 Some digestive system traits of guinea fowl at different ages

\begin{tabular}{|c|c|c|c|c|c|c|c|c|c|c|c|c|}
\hline $\begin{array}{l}\text { Production } \\
\text { system }\end{array}$ & $\begin{array}{c}\text { Slaughter } \\
\text { age } \\
\text { (weeks) }\end{array}$ & Sex & LW & TDT/LW (\%) & $\begin{array}{c}\text { Digestive } \\
\text { tract } \\
\text { length } \\
\text { (cm) }\end{array}$ & $\begin{array}{l}\text { SWILW } \\
\text { (\%) }\end{array}$ & $\begin{array}{l}\text { PWILW } \\
\text { (\%) }\end{array}$ & $\begin{array}{c}\text { Small } \\
\text { intestine } \\
\text { length } \\
\text { (cm) }\end{array}$ & $\begin{array}{c}\text { Large } \\
\text { intestine } \\
\text { length } \\
\text { (cm) }\end{array}$ & $\begin{array}{l}\text { Caecum } \\
\text { length } \\
\text { (cm) }\end{array}$ & $\begin{array}{c}\text { CWILW } \\
(\%)\end{array}$ & PRWILW (\%) \\
\hline \multirow{6}{*}{$\begin{array}{l}\text { Free- } \\
\text { range }\end{array}$} & \multirow{2}{*}{14} & M & 1056.1 & 2.09 & 124.90 & 0.07 & 0.14 & 85.18 & 7.73 & 11.93 & 0.35 & 0.20 \\
\hline & & $\mathrm{F}$ & 1003.5 & 2.21 & 125.63 & 0.06 & 0.18 & 88.63 & 8.18 & 12.85 & 0.33 & 0.20 \\
\hline & \multirow{2}{*}{16} & M & 1213.3 & 1.80 & 122.18 & 0.07 & 0.11 & 85.85 & 8.55 & 12.53 & 0.33 & 0.19 \\
\hline & & $\mathrm{F}$ & 1109.8 & 2.03 & 122.80 & 0.06 & 0.13 & 84.85 & 8.93 & 12.95 & 0.47 & 0.21 \\
\hline & \multirow{2}{*}{18} & M & 1290.1 & 1.86 & 119.18 & 0.05 & 0.12 & 80.73 & 9.43 & 12.45 & 0.34 & 0.17 \\
\hline & & $\mathrm{F}$ & 1196.3 & 1.97 & 119.83 & 0.04 & 0.14 & 80.90 & 9.88 & 12.58 & 0.38 & 0.22 \\
\hline \multirow{6}{*}{ Indoor } & \multirow{2}{*}{14} & $\mathrm{M}$ & 1094.9 & 2.08 & 119.18 & 0.05 & 0.14 & 85.93 & 8.78 & 13.02 & 0.29 & 0.20 \\
\hline & & $\mathrm{F}$ & 1004.8 & 2.00 & 121.90 & 0.04 & 0.15 & 91.55 & 8.60 & 12.05 & 0.36 & 0.24 \\
\hline & \multirow{2}{*}{16} & M & 1208.0 & 1.71 & 120.77 & 0.05 & 0.11 & 81.30 & 8.70 & 12.13 & 0.32 & 0.18 \\
\hline & & $\mathrm{F}$ & 1129.5 & 1.90 & 119.08 & 0.04 & 0.19 & 79.18 & 8.28 & 12.68 & 0.37 & 0.20 \\
\hline & \multirow{2}{*}{18} & M & 1287.5 & 1.91 & 118.05 & 0.04 & 0.12 & 79.60 & 7.93 & 12.75 & 0.36 & 0.17 \\
\hline & & $\mathrm{F}$ & 1197.0 & 1.82 & 117.25 & 0.03 & 0.13 & 81.45 & 8.38 & 12.00 & 0.36 & 0.19 \\
\hline SEM & & & 4.376 & 0,032 & 0,880 & 0.002 & 0.007 & 0.785 & 0.156 & 0.160 & 0.011 & 0.003 \\
\hline \multicolumn{13}{|l|}{ Effects } \\
\hline \multirow{2}{*}{\multicolumn{2}{|c|}{ Production system }} & $\mathrm{FR}$ & 1144.8 & 2.00 & 122.41 & 0.06 & 0.14 & 84.35 & 8.78 & 12.55 & 0.37 & 0.20 \\
\hline & & IN & 1153.6 & 1.90 & 119.37 & 0.04 & 0.14 & 83.17 & 8.44 & 12.44 & 0.35 & 0.20 \\
\hline \multirow{3}{*}{\multicolumn{2}{|c|}{ Slaughter age }} & 14 & $1039.6^{a}$ & $2.09^{a}$ & 122.90 & $0.05^{\mathrm{a}}$ & 0.15 & $87.82^{\mathrm{a}}$ & 8.32 & 12.46 & 0.33 & $0.21^{\mathrm{a}}$ \\
\hline & & 16 & $1165.1^{b}$ & $1.86^{\mathrm{b}}$ & 121.21 & $0.05^{a}$ & 0.13 & $82.79^{b}$ & 8.61 & 12.57 & 0.37 & $0.19^{b}$ \\
\hline & & 18 & $1242.7^{c}$ & $1.89^{b}$ & 118.58 & $0.04^{b}$ & 0.13 & $80.67^{b}$ & 8.90 & 12.44 & 0.36 & $0.19^{b}$ \\
\hline \multirow{2}{*}{\multicolumn{2}{|c|}{ Sex }} & M & 1106.8 & 1.91 & 120.71 & 0.05 & 0.12 & 83.10 & 8.52 & 12.52 & 0.33 & 0.19 \\
\hline & & $\mathrm{F}$ & 1191.7 & 1.99 & 121.08 & 0.04 & 0.15 & 84.43 & 8.70 & 12.47 & 0.38 & 0.21 \\
\hline \multicolumn{3}{|c|}{ Production system } & NS & NS & NS & NS & NS & NS & NS & NS & NS & NS \\
\hline \multicolumn{3}{|c|}{ Slaughter age } & ** & * & NS & ** & NS & ** & NS & NS & NS & * \\
\hline \multicolumn{3}{|l|}{ Sex } & $\star *$ & NS & NS & NS & NS & NS & NS & NS & * & ** \\
\hline
\end{tabular}

a, b: Means within columns with no common superscript letter differ significantly (*: $P<0.05 ; * *: P<0.01$ ), SEM: standard error of means, NS: insignificant; FR: free-range, IN: indoor; M: male, F: female

TDT/LW: ratio of total digestive tract weight to bodyweight, SW/LW: ratio of spleen weight to bodyweight,

PW/LW: ratio of pancreas weight to bodyweight, CW/LW: ratio of craw weight to body weight, PRW/LW: ratio of proventriculus weight to bodyweight 
that were reported in previous studies (Kokoszynski et al., 2011; Laudadio et al., 2012; Tufarelli \& Laudadio, 2015). However, in line with previous studies, breast-meat $L^{*}$ values in this study were higher than thighmeat $L^{*}$ values. Redness $\left(a^{*}\right)$ values in the present study ranged between $3.40-3.86$ for breast meat and 6.88 - 8.16 for thigh meat, which are lower than those reported by previous studies. For example, Kokoszynski et al. (2011) reported a* values of between 16.5 and 18.5 for breast meat and 17.1 and 18.6 for thigh meat. Similarly, Laudadio et al. (2012) found breast and thigh meat a* values to range between 16.15 and 8.89. Meat colour is highly correlated to the amount of compounds containing haem iron, namely myoglobin, haemoglobin and cytochrome (Froning et al., 1968; Fleming et al., 1991; Froning, 1995), with myoglobin making the most significant contribution of the three to poultry-meat colour (Wideman et al., 2016). Whereas breast meat is composed almost entirely of white fibres (Barbut, 2001), leg and thigh meat have large amounts of red fibres, which are higher in myoglobin compared with white fibres (Wideman et al., 2016), which explains why thigh meat $a^{*}$ values are normally higher than breast meat $a^{*}$ values. Colour values obtained in this study are in line with the demands of poultry consumers, who prefer white meat, particularly on the breast.

Another important factor that affects meat quality is $\mathrm{pH}$. A high $\mathrm{pH}$ value shortens meat shelf life, since it creates a more favourable environment for bacteria (Aberle et al., 2001; Chen et al., 2015). In the present study, $\mathrm{pH}$ values ranged between 6.56 and 6.79 for breast meat and 6.85 and 7.30 for thigh meat. Males had higher breast-meat $\mathrm{pH}$ values than females $(P<0.05)$. Similarly, guinea fowl reared indoors had higher thighmeat $\mathrm{pH}$ values $(P<0.01)$. Both breast- and thigh-meat $\mathrm{pH}$ values increased significantly with slaughter age $(P<0.01)$. In general, the $\mathrm{pH}$ values obtained in the current study were higher than those reported by previous studies. Laudadio et al. (2012) reported breast-meat pH values between 5.72 and 5.76 and thighmeat $\mathrm{pH}$ values between 5.79 and 5.81. Kokoszynski et al. (2011) found mean breast- and thigh-meat pH values to be 6.1 and 6.4 , respectively.

Water is one of the most important meat components in terms of the juiciness of fresh meat after cooking. Therefore, meat with a low WHC that loses large amounts of fluid during cooking may taste dry (Tlhong, 2008). In this study, the WHC of breast and thigh meat was not significantly affected by production system, slaughter age or sex. Kokoszynski et al. (2011) found breast- and thigh-meat WHC values to range between $61.3 \%$ and $64.2 \%$ and $64.4 \%$ and $69.6 \%$, respectively, and Laudadio et al. (2012) reported values of between $61.67 \%$ and $63.84 \%$; and $67.25 \%$ and $69.61 \%$, respectively, whereas our study measured higher values of between $72.20 \%$ and $75.12 \%$ and $75.76 \%$ and $77.80 \%$, respectively.

Both meat WHC and drip loss are affected by meat $\mathrm{pH}$, with $\mathrm{pH}$ values higher than 6.3 , as in the present study, being associated with a relatively dry meat surface and high WHC (Huff-Lonergan, 2002), which may be related to pre-slaughter stress. Poltowicz \& Doktor (2012) reported that slow-growing broilers showed increases in $\mathrm{pH}$ and decreases in drip loss in line with slaughter age. Similarly, the present study found drip loss was significantly lower among older guinea fowl $(P<0.01)$, whereas neither production system nor sex had a significant effect on drip loss. Overall, the drip-loss values in the present study (1.59\% $-4.96 \%)$ are in line with those for guinea fowl (2.31\% - 3.87\%) that were reported by Dahouda et al. (2009).

The digestive system regulates digestion and absorption in the body. In the present study, neither digestive-tract total weight/body weight ratio nor digestive-tract total length was significantly affected by production system or sex. This was the expected result because digestive system development of birds starts during incubation and is completed during growth of pullets. Reaching time to feed after hatch could have an effect on the growth, but in this study birds reared in both systems simultaneously had access to feed. Therefore, there was not a significant difference between systems and sex. Total digestive system length did not significantly change at different slaughter ages. After birds reach mature weights, digestive system completes its development and stays constant. But body mass continues to grow. Therefore, the ratio of total digestive weight to body weight decreased at older ages. However, small-intestine length decreased with age, which is in line with the findings of Kasperska et al. (2012). The spleen supplies oxygen to tissue and reinforces the immune system (John, 1994). According to John (1994), spleen weights of avian species increase rapidly after hatching and continue until sexual maturity. The spleen weight/bodyweight ratio was affected by significantly slaughter age $(P<0.05)$. This finding was expected, as it corresponds to the relatively higher body weights at older ages. A similar result was obtained in proventriculus weight/bodyweight ratio. All these organs completed their growth, but body weight significantly increased at older ages. Therefore, their relative ratios to bodyweight decreased at older ages.

According to the findings of this study, the meat quality of guinea fowl that are reared indoors and in a free-range system falls within acceptable limits for consumption. However, poultry producers may respond to increasing consumer concerns for animal welfare and thus demand animal-friendly production systems by turning to free-range systems as a more appropriate method of producing alternative poultry species such as guinea fowl. 
Acknowledgment

Authors are thankful to Abalioglu Feedmill Co. for their support.

\section{Authors' Contributions} manuscript.

MS designed the study and analysed data. MAB and AU collected data. USY collected data and designed the

\section{Conflict of Interest Declaration}

The authors declare that they have no affiliations with any organization or entity with any financial or non-financial interest that could bias the subject matter and outcomes discussed in this manuscript.

\section{References}

Aberle, E.D., Forrest, J.C. Derrard, D.E. \& Mills, E.W., 2001. Principles of meat science. 4th edition. Kendall/Hunt Dubuque, IA.

Ajala, M.K., Nwagu, B.I. \& Otchere, E.O., 2007. Socio-economics of free-range poultry production among agro-pastoral women in Giwa Local Government Area of Kaduna State, Nigeria. Nigeria Veterinary Journal 28 (3), 11-18.

Barbut, S., 2001. Basic anatomy and muscle biology. Poultry products processing: An industry guide. CRC Press Washington D.C. pp. 31-60.

Bernacki, Z., Bawej, M. \& Kokoszynski, D., 2012. Quality of meat from two guinea fowl (Numida meleagris) varieties. Arch. Geflugelkd. 76, 203- 207.

Bianchi, M., Petracci, M., Sirri, F., Folegatti, E., Franchini, A. \& Meluzzi, A., 2007. The influence of the season and market class of broiler chickens on breast meat quality traits. Poult. Sci. 86, 959-963.

Boz, M.A., Sarica, M. \& Yamak, U.S., 2017. Production traits of artificially and naturally hatched geese in intensive and free-range systems: I. Growth traits. Br. Poult. Sci. 58, 132-138.

$C A B, 1987$. The technical centre for agricultural and rural cooperation. Manual of poultry production in the tropics. Cambrian News Ltd, Aberytwyth, UK.

Castellini, C., Mugnai, C. \& Dal Bosco, A., 2002. Effect of organic production system on broiler carcass and meat quality. Meat Sci. 60, 219-225.

Chen, Y., Aorigele, C., Yan, F., Li, Y., Cheng, P. \& Qi, Z., 2015. Effect of production system on welfare traits, growth performance and meat quality of ducks. S. Afr. J. Anim. Sci. 45, 173-179.

Dahouda, M., Toleba, S.S., Youssao, A.K.I., Mama Ali, A.A., Dangou-Sapoho, R.K., Ahounou, S.G., Hambuckers, A. \& Hornick, J-L., 2009. The effects of raw and processed Mucuna pruriens seed-based diets on the growth parameters and meat characteristics of Benin local guinea fowl (Numida meleagris, L). Int. J. Poult. Sci. 8 (9), 882-889.

Fanatico, A.C., Pillai, P.B., Emmert, J.L. \& Owens, C.M., 2007. Meat quality of slow- and fast-growing chicken genotypes fed low nutrient or standard diets and raised indoors or with outdoor access. Poult. Sci. 86, 2245-2255.

Fleming, B.K., Froning, G.W. \& Yang, T.S., 1991. Haem pigment levels in chicken broilers chilled in ice slush and air. Poult. Sci. 70, 2197-2200.

Fletcher, D.L., 1992. Methodology for achieving pigment specifications. Poult. Sci. 71:733-743.

Froning, G.W., 1995. Colour of poultry meat. Poultry and Avian Biological Reviews 6, 83-93.

Froning, G.W., Daddario, J. \& Hartung, T.E., 1968. Colour and myoglobin concentration in turkey meat as affected by age, sex and strain. Poult. Sci. 47, 1827-1835.

Huff-Lonergan, E., 2002. Water-holding capacity of fresh meat. Fact sheet (04669). National Pork Board, Des Moines, IA., USA.

John, J.L., 1994. The avian spleen: A neglected organ. The Quarterly Review of Biology 69 (3), 327-351.

Kasperska, D., Kokoszynski, D., Korytkowska, H. \& Mistrzak, M., 2012. Effect of age and sex on digestive tract morphometry of guinea fowl (Numida meleagris L.). Folia Biologica 60 (1-2), 45-49. Doi:10.3409/fb60_1-2.45-49

Kokoszynski, D., Bernacki, Z., Korytkowska, H., Wilkanowska, A. \& Piotrowska, K., 2011. Effect of age and sex on slaughter value of guinea fowl (Numida meleagris). Journal of Central European Agriculture 12, 255-266.

Laudadio, V., Nahashon, S.N. \& Tufarelli, V. 2012. Growth performance and carcass characteristics of guinea fowl broilers fed micronized-dehulled pea (Pisum sativum L.) as a substitute for soybean meal. Poult. Sci. 91, 2988-2996.

Madzimure, J., Saina, H. \& Ngorora, G.P.K., 2011. Market potential for guinea fowl (Numidia meleagris) products. Trop. Anim. Health Prod. 43,1509-1515. doi: 10.1007/s11250-011-9835-z

Nikolova, N., Pavlovski, Z., Milosevic, N. \& Peric, I., 2007. The quantity of abdominal fat in broiler chicken of different genotypes from fifth to seventh week of age. Biotechnol. Anim. Husb. 23, 331-338.

Poltowicz, K. \& Doktor, J., 2012. Effect of slaughter age on performance and meat quality of slow-growing broiler chickens. Annals of Anim. Sci. 12 (4), 621-631.

Saina, H., 2005. Guinea fowl (Numidia meleagris) production under smallholder farmer management in Guruve District, Zimbabwe. Master of Philosophy thesis, University of Zimbabwe, Harare, Zimbabwe.

Sarica, M.,. Ocak, N., Turhan, S., Kop, C. \& Yamak, U.S., 2011. Evaluation of meat quality from 3 turkey genotypes reared with or without outdoor access. Poult. Sci. 90, 1313-1323.

TIhong, T.M., 2008. Meat quality of raw and processed guinea fowl (Numeda meleagris). Master's thesis, Stellenbosch University, South Africa. pp. 138. 
Tufarelli, V. \& Laudadio, V., 2015. Feeding of dehulled-micronized faba bean (Vicia faba var. minor) as substitute for soybean meal in guinea fowl broilers: Effect on productive performance and meat quality. Asian-Austral. J. Anim. Sci. 28 (10), 1471-1478.

Wideman, N., O'Bryan, C.A. \& Crandall, P.G., 2016. Factors affecting poultry meat colour and consumer preferences - A review. Wrld's Poult. Sci. J. 72, 353-366.

Yamak, U.S., Sarica, M., Boz, M.A. \& Ucar, A., 2016. The effect of production system (barn and free-range), slaughtering age and gender on some carcass traits and meat quality of partridges (Alectoris chukar). Br. Poult. Sci. 57, 185-192. 